\title{
Upaya Meningkatkan Hasil Belajar IPS Melalui Media Permainan Ular Tangga pada Peserta Didik Kelas VI SD Negeri 104/IX Kedemangan Kabupaten Muaro Jambi
}

Jamalia

SD Negeri 104/IX Kedemangan jamalia747@gmail.com

\begin{abstract}
Thepurpose of this research is to improve results learning subjects IPS through snake ladder media on grade 6 students SD No 104 / IX Kedemangan Muaro Jambi District Academic Year 2012/2013. The low learning interest of students in following the subjects of Social Sciences (IPS) which causes lowlearning outcomes of students is a major element of this research. The form of research is action research which is implemented in three cycles/ series. each cycle/ series consists of four stages namely, planning, action, observation, and reflection. There were 27 subjects, consisting of 11 males and 16 females. The method used as the main method is observation and test. The results showed that through the game media snake ladder the increased learning outcomes of IPS students, in the pre-action of the learners overall learning outcomes show percentage of $7.40 \%$ of students learn complete, after the first cycle/ series of learning results have increased in the amount of 40.74\%. However the school established KKM 60 with percentage 100\% complete, the action continued in II cycle/series and then result increased by $70.37 \%$. and then the action is continued in III cycle/series with result score of $100 \%$ complete. it can be concluded that through the game media snake ladder can improve learning outcomes of IPS in grade 6 students SD 104 / IX Kedemangan muaro jambi district academic year 2012/2013.
\end{abstract}

Keywords: Effort, Results Learning Outcomes, IPS, Snake Ladder Game Media

\section{Pendahuluan}

Dunia kini semakin terbuka. Keterbukaan itu kian hari kian cepat. Evolusi perkembangan didukung oleh infrastruktur transportasi yang memungkinkan terjadinya mobiltitas manusia yang super cepat sehingga menimbulkan terjadinya perpindahan dan pertukaran informasi yang cepat pula. Pengembangan dimaksud yaitu pengembangan infrastruktur transportasi maupun teknologi komunikasi, merupakan penjelasan tentang kenyataan dunia kemarin, kini dan hari esok selanjutnya keadaan tersebut berujung pada pendefinisian keadaan sosial dan perkembangan masyarakat, sebagai salah satu responsnya dalam kancah Pendidikan, Indonesia telah menyiapkan pelajaran Ilmu Pengetahuan Sosial (IPS) bagi perserta didik, khsusunya di sekolah dasar sebagai pondasi ilmu pengetahuan untuk menjawab tantangan tersebut. Pelajaran Ips termasuk salah-satu mata pelajaran yang amat penting dikuasai sejak tingkat sekolah dasar sebagaimana GBPP Kurikulum Pendidikan Dasar, (1999) menyatakan; 
Fungsi pelajaran IPS di Sekolah Dasar adalah untuk mengembangkan sikap rasional tentang gejala-gejala sosial serta wawasan tentang perkembangan masyarakat Indonesia dan masyarakat dunia di masa lampau dan masa kini. Sedangkan tujuan mata pelajaran IPS di Sekolah Dasar adalah untuk mengambil akan pengetahuan dan keterampilan dasar yang berguna bagi peserta didik dalam kehidupan sehari-hari serta mampu mengembangkan pemahaman tentang perkembangan masyarakat Indonesia sejak masa lalu hingga masa kini, sehingga peserta didik memilki kebanggaan sebagai bangsa Indonesia dan cinta kepada tanah air.

Melalui mata pelajaran IPS, peserta didik diarahkan untuk menjadiwarga negara Indonesia yang demokratis dan bertanggung jawab. Pendidikan diIndonesia diusahakan agar lebih maju dan bermutu. Upaya peningkatan mutupendidikan dilaksanakan antara lain dengan mengusahakan penyempurnaan prosesbelajar mengajar guna meningkatkan hasil belajar peserta didik.

Pelajaran IPS yang cakupannya beragam dan luas serta tuntutan kurikulum yang sarat dengan muatan yang harus disampaikan kepada peserta didik dengan alokasi waktu yang terbatas, guru mengalami kesulitan dalam menyajikan bahan ajar IPS dengan baik, menarik, dan menantang minat belajar, pada akhirnya pembelajaran IPS yang dilaksanakan guna mengejar target materi pelajaran. Sehingga hasil belajar peserta didikpun cenderung tidak sesuai dengan harapan.

Berdasarakan studi pendahuluan ditemukan bahwa proses belajar mengajar IPS umumnya dipersepsikan tidak menarik dan tidak begitu penting hal tersebut dikarenakan beberapa faktor diantaranya:

1. Penempatan jam pelajaran IPS cenderung sebagai pelengkap, yang ditempatkan pada jam pelajaran terakhir dimana kondisi belajar peserta didik sudah menurun;

2. Guru merasa kewalahan dalam mempersiapkan setiap mata pelajaran karena beban mengajar yang tidak seimbang;

3. BukuIPS umumnya tebal-tebal dengan materi pelajaran yang terlalu berat dan bahasa baku yang sulit dicerna, akibatnya peserta didik tidak mampu belajar mandiri;

4. Kurangnya kemampuan guru dalam menerapkan variasi model pembelajaran yang dapat menarik minat dan menciptakan pembelajaran menjadi menyenangkan.

Akibat beberapa faktor di atas dampaknya terlihat jelas pada respon dan sikap peserta didik yang berujung pada rendahnya hasil belajar, respon dimaksud diantaranya peserta didik cenderung pasif ketika memasuki jam pelajaran, peserta didik menunjukkan ekspresi yang biasa-biasa saja ketika mendengar masuknya jam pelajaran, bahkan masih ditemukan peserta didik menunjukkan sikap penolakan terhadap pelajaran dengan perilaku membolosnya, sedangkan dalam proses pelajaran peserta didik mudah mengantuk, sibuk dengan aktivitasnya sendiri, dan masih ditemukan adanya siswa yang tidak mempunyai keingintahuan terhadap pelajaran, akibatnya hasil belajar siswa menjadi rendah yaitu dari 27 siswa kelas VI hanya dua siswa yang telah tuntas memenuhi kriteria ketuntasan minimal (KKM) 60 sebagaimana yang ditetapkan sekolah.

Fenomena tersebut mengindikasikan bahwa diperlukannya sikap dan langkah tepat guru sehingga peserta didik mendapatkan ketuntasan belajar100\% secara klasikal sebagaimana yang dipersyaratkan sekolah.Selanjutnya berdasarkan kajian literature dan beberapa temuan hasil penelitian menunjukkan bahwa permainan ular tangga merupakan permainan yang digemari siswa maka, peneliti tertarik menjadikannya sebagai media dalam pelajaran. Adapun yang menjadi rumusan 
masalah dalam penelitian ini yaitu bagaimana media permainan ular tangga untuk meningkatkan hasil belajar siswa kelas VI mata pelajaran IPS pada kompetensi dasar membandingkan gejala alam dan keadaan sosial yang ada di Indonesia dan Negara-negara tertangga. Dengan tujuan penelitian untuk mengetahui media permainan ular tangga dapat meningkatkan hasil belajar siswa pada mata pelajaran Ips kelas VI SD 104/IX Kedemangan, sedangkan manfaat penelitian yaitu sebagai bahan masukan bagi guru bahwa media permainan ular tangga dapat dijadikan sebagai salah satu alternatif dalam meningkatkan hasil belajar mata pelajaran Ips, meningkatkan kemampuan peserta didik mengembangkan potensi diri secara optimal terutama dalam belajar IPS ke depannya, memberikan masukan kepada sekolah dalam usaha perbaikan proses pembelajaran, sehingga berdampak pada peningkatan mutu sekolah serta memberikan konstribusi akademis dalam pengembangan teori bidang ilmu yang diteliti bagi praktisi.

Belajar merupakan kegiatan yang tidak terpisahkan dari kehidupan manusia dan dilakukan oleh setiap orang untuk memperoleh suatu pengetahuan baru.Piaget (Dimyati,Mudjiono, 2006:13) menyatakan bahwa pengetahuan dibentuk oleh individu. Sebab individu melakukan interaksi terus menerus dengan lingkungannya dan lingkungan tersebut mengalami perubahan sehingga fungsi intelek semakin berkembang. Lebih lanjut Wellton DA Mallan (1996:196) mengemukakan belajar adalah proses perubahan pengetahuan atau perilaku sebagai hasil dari pengalaman. Pengalaman ini terjadi melalui interaksi antaraIndividu dengan lingkungannya. Sementara itu Kurnidar (2002:53) menyatakan belajar adalah suatu aktivitas mental/psikis yang berlangsung dalam interaksi yang aktif dengan lingkungan,yang menghasilkan perubahan-perubahan dalam pengetahuan, pemahaman, keterampilan dan nilai sikap.

Suatu proses belajar akan lebih efektif jika menerpadukan model, strategi, atau metode pembelajaran dengan media. Seperti yang diungkapkan oleh Munandar (1999:56) bahwa media adalah bagian yang tidak terpisahkan dari proses belajar mengajar demi tercapainya tujuan pendidikan pada umumnya dan tujuan pembelajaran disekolah pada khususnya. Media dapat mewakili apa yang kurang mampu guru ucapkan melalui kata-kata atau kalimat tertentu(Nasution,2013:120).

Media yang digunakan dalam pembelajaran dapat disebut sebagai media pembelajaran. Media mempunyai arti yang lebih luas lagi seperti yang diungkapkan Mustari, M (2014: 6) bahwa media pembelajaran adalah segala sesuatu (baik manusia, benda, atau lingkungan sekitar) yang dapat digunakan untuk menyampaikan atau menyalurkan pesan dalam pembelajaran sehingga dapat merangsang perhatian, minat, pikiran,dan perasaan siswa pada kegiatan belajar untuk mencapai tujuan.

Media permainan ular tangga adalah permainan papan untuk anak-anak yang dimainkan oleh 2 orang atau lebih. Papan permainan dibagi dalam kotak-kotak kecil dan di beberapa kotak digambar sejumlah "tangga" atau "ular" yang menghubungkannya dengan kotak lain. Permainan ini diciptakan pada tahun 1870 (www.Wikipedia.org, diakses 27 Juni 2012., 16:33).

Pengelompokan jenis-jenis media pembelajaran banyak disampaikan oleh para ahli. Apabila dilihat dari segi perkembangan teknologinya, Munandar, (1999: 33-35) membagi media kedalam dua kategori luas, yaitu media tradisional dan media teknologi mutakhir. Media permainan ular tangga masuk kedalam kategori media tradisional yaitu permainan dan media visual karena dalam media permainan ular tangga terdapat gambar, bermacam-macam bentuk dan warna. Hal tersebut bermaksud menumbuh kembangkan daya tarik peserta didik sebagaimana Nasution(2013:107-112) dalam proses penataan media, harus diperhatikan prinsip- 
prinsip kesederhanaan, keterpaduan, penekanan, dan keseimbangan. Sedangkan unsur-unsur visual yang perlu dipertimbangkan yaitu bentuk, garis, ruang, tekstur, dan warna.

\section{Metode}

Jenis penelitian ini yaitu penelitian tindakan kelas (action research) penelitian tindakan kelas merupakan penelitian yang dilakukan oleh guru di dalam kelasnya sendiri melalui refleksi diri dengan tujuan untuk memperbaiki kinerjanya sebagai guru sehingga kualitas proses dan hasil belajar siswa meningkat (Cresswell, 2008), lokasi penelitian yaitu SDN no 104/IX Kedemangan Kabupaten Muaro Jambi, waktu penelitian yaitu semester dua tahun ajaran 2012/2013, subjek penelitian yaitu peserta didik kelas VI yang berjumlah 27 siswa terdiri dari 12 laki-laki dan 15 perempuan. Teknik pengumpulan data menggunakan penilaian tertulis untuk memperoleh data hasil belajar Ips, observasi kinerja guru dalam bentuk indicator keberhasilan guru dan aktivitas belajar siswa dalam bentuk indikator keberhasilan siswa, prosedur penelitian terdiri dari rencana (planning); pelaksanaan tindakan (action); pengamatan/ observasi (observation); dan refleksi (reflection) (Creswell, 2008). Data hasil dianalisis dengan persentase sederhana.

\section{Hasil}

Dari hasil penelitian yang dilakukan tentang upaya meningkatkan hasil belajar Ips melalui media permainan ular tangga pada peserta didik kelas VI SD no 104/IX kedemangan kabupaten muaro jambitahun ajaran 2012/2013 dapat diuraikan sebagai berikut:

\section{Siklus I}

Setelah menempuh tahapan rencana dan pelaksanaan tindakan penelitian pada siklus I ketuntasan belajar peserta didik meningkat menjadi 40,74\% secara klasikal yang sebelumnya $7,40 \%$, nilai tertinggi 72 dan nilai terendah 45 dengan rata-rata skor 50, sedangkan observasi aktivitas guru dari 10 indikator keberhasilan sebesar 27,5 dan aktivitas siswa dengan 10 indikator keberhasilan sebesar 16 dengan persentase $32 \%$ dalam kategori cukup.

Berdasarkan pelaksanaan kegiatan yang dilaksanakan pada siklus I menghasilkan perubahan hasil belajar peserta didik yang signifikan namun ketuntasan peserta didik belum mencapai $100 \%$ sebagaimana yang ditetapkan oleh sekolah. Hal ini dikarenakan beberapa faktor yaitu sebagai manajemen waktu guru dalam membuat rencana dan menyampaikan materi pelajaran, penggunaan Bahasa yang dapat dipahami dengan baik oleh siswa, serta penguasaan kelas yang dapat mengaktifkan, guru model belum maksimal dalam menyajikan pelajaran (bahasa yang kurang menarik dan runut sehingga terkesan jenuh bagi peserta didik), kurangnya kompetensi penguasaan kelas sehingga memberikan peluang adanya peserta didik tidak fokus mengikuti pelajaran, Adapun disisi peserta didik yaitu, kurangnya konsentrasi dalam melakukan permainan hal ini berdasarkan pengamatan observer adanya peserta didik yang mengganggu temannya, peserta didik yang membacakan soal menggunakan suara yang kurang jelas, ketika peserta didik berusaha menjawab pertanyaan beberapa peserta didik lain berusaha mengelabuhi jawaban hal itu ditunjukkan saat peserta didik terlihat tidak nyaman/ gelisahnya saat berada ditempat duduk.

Oleh karena perolehan hasil belajar peserta didik pada siklus I menunjukkan masih ada beberapa peserta didik yang belum memenuhi ktriteria ketuntasan minimal maka tindakan dilanjutkan pada siklus kedua 


\section{Siklus II}

Setelah menempuh beberapa perbaikan dari hasil refleksi siklus I selanjutnya hasil belajar siswa pada siklus II meningkat dari $40,74 \%$ menjadi $70,37 \%$ secara klasikal, nilai tertinggi 80 dan nilai terendah 55 dengan rata-rata skor 58 , sedangkan observasi aktivitas guru dari 10 indikator keberhasilan meningkat dari 27, 5 menjadi 34,3 dan aktivitas siswa dengan 10 indikator keberhasilan dengan total skor 16 meningkat menjadi 48 dengan persentase $82 \%$ dalam kategori Baik.

Berdasarkan pelaksanaan kegiatan yang dilaksanakan pada siklus II menghasilkan perubahan hasil belajar peserta didik yang signifikan, namun masih ditemuan beberapa peserta didik yang belum mencapai ketuntasan KKM sebesar 60, setelah menempuh tahapan refleksi ditemukan beberapa faktor yang perlu dibenahi diantaranya nada dan intonasi suara guru yang, menajemen waktu penyampaian materi pelajaran dan perhatian intensif kepada siswa yang diduga mengalihkan konsentrasi siswa lainnya,dengan demikian tindakan dilanjutkan lagi pada siklus III.

\section{Siklus III}

Setelah melakukan sejumlah perbaikan sebagaimana yang ditemukan pada kegiatan refleksi siklum II, ditemukan bahwa hasil belajar siswa pada siklus III meningkat dari 70,37\% menjadi 100\% secara klasikal, sedangkan aktivitas guru dari 10 indikator keberhasilan meningkat dari 34,3 menjadi 40,0 dengan persentase $100 \%$, aktivitas siswa 10 indikator keberhasilan meningkat dari total skor 16 menjadi $100 \%$. Hasil tersebut mengandung arti secara keseluruhan hasil belajar siswa dinyatakan tuntas sesuai dengan KKM sebesar 60 dengan persentase $100 \%$ yang ditetapkan sekolah. Dengan demikian penelitian tindakan kelas ini dapat diakhiri pada siklus III.

\section{Pembahasan}

Pada siklus I setelah diadakan tes kemampuan awal dilanjutkan dengan peserta didik medengarkan penjelasan guru mengenai strategi memainkan media ular tangga yang dimulai dengan kegiatan awal berupa ekspresi peserta didik permainan ini disebut "ekspresi gajah dan semut".

Setelah dilaksanakan siklus I dan dievaluasi dapat dilihat adanya peningkatan hasil belajar yaitu kondisi awal prosentase ketuntasan belajar peserta didik sebesar 7.40 $\%$ sedangkan pada siklus I hasil belajar peserta didik mencapai $40.74 \%$, dengan nilai terendah 45 , nilai tertinggi 72 dan rata-rata nilai peserta didik sebesar 50, oleh karena masih ditemukan peserta didik yang belum tuntas maka tindakan dilanjutkan dengan siklus II, pada siklus II terjadi peningkatan hasil belajar peserta didik yaitu ketuntasan belajar sebesar $70.35 \%$, nilai terendah 55 , nilai tertinggi 80 dan rata-rata nilai peserta didik 58, tindakan dilanjutkan lagi pada siklus III dikarenakan ada beberapa siswa masih ada yang belum tuntas sesuai KKM maka, pada siklus III terjadi pula peningkatan prestasi belajar peserta didik yaitu secara keseluruhan peserta didik sudah dinyatakan tuntas atau memenuhi kriteria ketuntasan minimal KKM 60. Adapun beberapa faktor yang perlu diperbaiki diantaranya manajemen waktu guru dalam membuat rencana dan menyampaikan materi pelajaran, penggunaan Bahasa yang dapat dipahami dengan baik oleh siswa, serta penguasaan kelas yang dapat mengaktifkan.

\section{Kesimpulan}

Berdasarkan hasil penelitian dan pembahasannya dapat disimpulkan bahwa melalui media permainan ular tanga dapat meningkatkan hasil belajar peserta didik kelas 
VI SD 104/IX kedemangan kota kabupaten muaro jambi pada pelajaran IPS kompetensi dasar membandingkan gejala alam dan keadaan sosil di Indonesia dan Negara-negara tertangga. Hal tersebut dapat dilihat dari peningkatan hasil belajar peserta didik dari siklus I, II dan siklus III.

\section{Saran}

Adapun saran yang dapat diberikan dari temuan hasil penelitian ini yaitu: pertama bagi sekolah; Penelitian dengan classroom action research atau penelitian tindakan kelas memberikan kontribusi terhadap penigkatan mutu pembelajaran di sekolah; kedua bagi guru bahwa untuk meningkatkan hasil balajar IPS diharapkan menggunakan bantuan media permainan ular tangga; untuk meningkatkan keaktifan, kreativitas peserta didik dan keefektifan pembelajaran diharapkan menerapkan pembalajaran dengan bantuan media permainan ular tangga; untuk memperoleh jawaban yang tepat, sesuai dengan tujuan penelitian disarankan untuk menggali pendapat atau tanggapan peserta didik dengan kalimat yang lebih mengarah pada proses pembelajaran dengan media permainan ular tangga. Ketiga bagi peserta didik hendaknya dapat berperan aktif dengan menyampaikan ide atau pemikiran pada proses pembelajaran, sehingga proses pembelajaran dapat berjalan dengan lancar sehingga nantinya akan memperoleh hasil belajar yang optimal; peserta didik dapat mengaplikasikan hasil belajarnya ke dalam kehidupan seharihari.

\section{DAFTAR PUSTAKA}

Creswell, J. W. (2008). Education Research; Planning, Conducting, and Evaluating Quantitative and Qualitative Research (Third ed.). Amerika: Pearson Education., Inc

Departemen Pendidikan Dan Kebudayaan (1999), Penyempurnaan Penyesuaian Kurikulum 1999, Jakarta, Depdikbud

Dimyati dan Mudjiono. (2006). Belajar dan pembelajaran. Jakarta: Rineka Cipta bekerjasama dengan Depdipbud

Hurlock, E. B. (1990). Development Psychology: A Life Span Appraisal. New York: McGraw Hill Inc

Kurnidar (2002), Ilmu Pengetahuan Sosial Jilid 1: Untuk Sekolah Dasar Kelas 6 Bandung, PT Sarana Panca Karya Nusa.

Munandar. (1999). Kreativitas dan Keberbakatan Strategi Mewujudkan Potensi Kreatif (1 ed.). Jakarta: Gramedia

Mustari, M. (2014). Manajemen Pendidikan. Jakarta: PT RajaGrafindo Persada

Nasution. (2013). Berbagai Pendekatan dalam Proses Belajar \& Mengajar (16 ed.). Jakarta: PT Bumi Aksara.

Permana J, dan Sumantri M, 1999, Strategi Belajar Mengajar, Jakarta, Ditjen Dikti, Depdikbud

Wellton DA Mallan, (1996), Children and Their World, Strategic for Teaching Social Studies, Boston Houston: Mifflin Company

www. Wikipedia.org 